\title{
RASSF1 Gene
}

National Cancer Institute

\section{Source}

National Cancer Institute. RASSF1 Gene. NCI Thesaurus. Code C60665.

This gene plays a role in the maintenance of genomic integ rity and possibly tumor suppression. 